\section{PJIEE}

Premise : Journal of English Education and Applied Linguistics

https://fkip.ummetro.ac.id/journal/index.php/english

Mahmud

\title{
AN ANALYSIS OF EFL JUNIOR HIGH SCHOOL STUDENTS' DIFFICULTIES IN SPEECH PRODUCTION
}

\author{
by \\ Yogi Saputra Mahmud \\ Faculty of Education, Monash University Australia \\ yogi.mahmud@monash.edu
}

Received: August 31, 2018

Accepted: September7, 2018
Reviewed: September 3, 2018

Published: October 1, 2018

\begin{abstract}
:
This study aims to discover the students' difficulties in retelling their experiences. Nine Junior High School students participated in this study. Two research instruments were utilized to collect the research data, including spoken text analysis and students' interview. By analyzing the linguistic features and generic structures of the students' spoken texts, it is discovered that all students had constructed their stories based on the required elements of recounts. However, most of the students did not elaborate their personal comments on the texts they have spoken. In relation to the grammatical errors, misformation becomes the most general errors found in the students' spoken texts, followed by omission, addition, and misordering. The students are also interviewed to reveal their perceptions regarding their speaking difficulties. Based on the interview, limited understanding of verbal forms, vocabularies, as well as anxiety or nervousness are identified as the possible causes of the students' difficulties. This study also provides further suggestions and implications for classroom teachers as well as recommended directions for future researchers in the relevant field.
\end{abstract}

Keywords: error analysis, recount, speaking, students' difficulties.

\section{INTRODUCTION}

Speaking is a medium to express ideas, intentions, thoughts, and feelings to other people by using oral language. From this definition, it can be argued that speaking skill involves people who communicate their ideas with other people orally. Regarding the purposes of speaking skill, it is argued that there are two distinct purposes of spoken language, including interpersonal and transactional purposes (Brown \& Yule, as cited in Sudjasmara, 2013). Speaking skill for interpersonal purpose relates to the use of speaking skills to establish and maintain the social relationship with others. Since people are considered as social subjects, who need to interact with others, speaking play 
a significant role within the society. Meanwhile, speaking skill for transactional purposes deal with the use of speaking skill to transmit and convey information to others.

In addition, speaking is also considered as the most critical skill among the four essential language skills in learning a second language (Khamkhien, 2010). This is because all other relevant skills of understanding the language are also included in speaking activities (Ur, as cited in Khamkhien, 2010). For students, speaking can be a medium where a new language structure, expressions, and vocabularies are encountered, understood, as well as practiced (Al Hosni, 2014). Consequently, students might face difficulties when they engage in conversational activities in EFL classrooms. In addition, this statement is also supported to the fact that the existing studies reveal that EFL students, especially at the initial and intermediate learning stages, may find it difficult to engage in speaking activities due to a number of reasons, including grammatical errors, anxiety, etc. (Haidara, 2016; Juhana, 2012; Noprival, 2016).

Several studies have discovered that speaking in the EFL setting is one of the most challenging skills for the students (Dalem, 2017; Yang \& Chang, 2008). The students might find it challenging to master the speaking skill since they are not used to practice the language in their daily life due to the foreign language setting (Sayuri, 2016). In addition, it can also be argued that speaking fluently and accurately is a complicated undertaking since the students need to talk and think simultaneously. Besides of that, there are also several elements involved when the students attempt to engage in speaking activities, including pronunciation, grammar, vocabulary, fluency, and comprehension (Sayuri, 2016). Consequently, it can also be stated that the Indonesian EFL students can also experience similar difficulties when they try to conduct speaking/conversational activities in the classroom.

Although studies discover the students' difficulties in speaking activities, the errors or mistakes that they produce are not merely seen as weaknesses for the students. Errors are no longer considered something sinful due to the inevitability to avoid the existence (Fauziati, 2011; Nagaraj, as cited in Hojati, 2013). In addition, the errors produced by the students can further become a field of enquiry for researchers to analyze the students' difficulties to learn L2. Furthermore, Hidayati (2011) adds that the students' errors can be the essential part of students' learning process which can 
provide vital insights into the process of language acquisition. Therefore, exploring the errors produced by the students in their spoken texts can be vital information to inform which language aspects they need to develop further.

Based on the latest curriculum implemented in Indonesia, the 2013 curriculum, one of the speaking activities that should be mastered by Junior High School students is retelling past experiences both in oral and written productions (see Ministry of Education and Culture, 2016). In other words, the students will engage with recount text both in spoken and written forms. Schleppegrell (2004) defines recount as a text which retells a sequence of events drawing upon personal experiences. Furthermore, it is also composed by the record of events and experiences which happened one after the other (Emilia, 2011). Recount text also has distinct characteristics of generic structures and linguistic features that will be explored further below.

Recount, which has functions to retell or inform past events or experiences, consists of three generic structures, including orientation, records of events, and reorientation (Emilia, 2011). Orientation is a part which informs other people by introducing characters in a setting of time or place. Meanwhile, records of events consist of several events or moments experienced by the writers/speakers in their experiences. In addition, the writers/speakers can also include the optional part in a recount text, namely reorientation that includes their personal feeling or comments toward the experiences they experience. Based on the explanation above, this study also explores the students' stories based on the generic structure of recount to analyze whether they have already developed their stories with the appropriate structure of recount text. Furthermore, this study also analyses the linguistic features of the students' stories that will be explored deeper in the following paragraph.

According to Emilia (2011), there are several linguistic features of recount text, including the use of specific participants, the use of circumstance of time and place, the use of first person, the use of additive conjunction, the use of material processes, as well as past tense. Specific participants include the use of specific characters' names or features within a story, such as "brother", "sister", "father", etc. Meanwhile, the circumstances of time and place are used to describe the setting of time and place within a story, such as "last three weeks", "at the park", etc. The use of first person in a recount text usually consists of the use of "I" and "we" since the nature of recount text is viewed 
from personal experiences. Furthermore, the use of material processes represents the process of doing and happening, which includes "played", "went", etc. The use of additive conjunction, such as "then", "after that", etc. is essential to relate one event to another within a story. Ultimately, past tense form is used to represent the activities happened in the past. Consequently, the students should be able to master these linguistic features to develop speaking skills, particularly in retelling past experiences.

Even though several EFL researchers in Indonesia have already focused on analyzing the students' difficulties in recount text (see Agustina, 2016; Hamid \& Qayyimah, 2014; Hermini, 2015), the studies mainly focus on writing skill and the errors in grammatical levels. Therefore, the researcher also attempts to focus on exploring the spoken form of recount, in which the researcher attempts to depict the students' difficulties in retelling past experiences by analyzing the generic structure and grammatical structure of their stories. To understand the phenomenon further, it is also essential to discover which aspects or types of error that the students produce in their stories. Consequently, Surface Strategy Taxonomy is also involved in this study to identify the error types that the students produce that will be explored further below.

Dulay, Burt, and Krashen's (1987) Surface Strategy Taxonomy is often utilized as a frame of reference to categorize the types of errors produced by the students in their stories. The taxonomy emphasizes the ways surface structures which are altered in specific and systematic ways. By utilizing this taxonomy, this study attempts to discover whether the students' errors are categorized into omission, misformation, or misordering types. These categories can further inform which aspects that should be mastered by the students in retelling past experiences. These four categories are explained further in the following paragraph.

Addition is indicated by the presence of an inappropriate item in sentences which will not be likely to appear in a correct sentence. This error usually occurs in the later stages of second language acquisition. There are three types of addition have been observed, such as double markings, regularization and simple addition. Double marking often occurs due to the failure to delete particular items needed in some linguistic construction. Regularizations is a type of error where a marker is erroneously added in unnecessary linguistic items, for example (Where I have to do it on the top of big bridge 
on Taman lansia). Simple addition which characterizes all addition errors, for example (we went to upstairs).

Omission is the opposite of addition. It is indicated by the absence of necessary items in sentences to avoid misunderstandings. This kind of error occurs during the early stages of second language acquisition. For example, my mother very happy. It should be my mother is very happy. Furthermore, omission can also include in the absence of the article, preposition/circumstances, as well as other linguistic features.

Misformation is indicated by the wrong use of morphemes and structure when using one grammatical form in place of particular grammatical form. It may create misunderstanding between speaker and listener. For example, I eated fried chicken yesterday. There are three types of misformation, such as regularizations, archi-forms, and alternating forms. Regularization is the generalization of learners to use particular words to describe plurality or different tenses with the wrong form, for example, we were gifted Cubit cakes. Archiforms is the choice of a class form to describe another class form in a different situation, for example, Last three weeks, I go to a museum. Alternating forms. It occurred when the learners used some forms alternatively which result in producing a wrong word, for example, Those cat, This cats, the use of the wrong form of preposition, such as at the second floor.

Misordering is indicated by the incorrect placement of particular morphemes in an utterance. For example, we don't remember where is his brother, instead of we don't remember where his brother is. This kind of error can be influenced by word-for-word translations of native language surface structures (Dulay, Burt and Krashen, 1987).

From the discussion above, this paper aims to answer these research questions:

1. What are the students' difficulties at the level of generic structure and linguistic features to retell past experiences?

2. What are the types of errors that the students produce in their spoken texts?

3. What are the possible causes of the students' difficulties to retell past experiences?

While the discussion in this paper can be a reference to enrich the knowledge in the relevant area, it can also enlighten teachers in addressing the language aspects that the students find it difficult to practice and master to develop their speaking skills.

Premise Journal Vo. 7 No 2, October 2018, e-ISSN: 2442-482x, p-ISSN: 2089-3345, page 15-33 Copyright@2018by 


\section{METHOD}

\section{Design}

This study implemented a mixed-method approach which settles both quantitative and qualitative approaches to gather the research findings and further to answer the research questions. The idea of a mixed-method approach relates to the procedure of collecting, utilizing, and analyzing the combination between quantitative and qualitative data to provide a better understanding of the phenomenon, and the relationship between variables being investigated (Creswell, 2012). In this case, quantitative approach is applied to measure the proportion of students' errors in their speech production while the underlying difficulties experienced by the students are measured through qualitative approach.

\section{Participant}

This study was conducted at one private Junior High School in Bandung, West Java that involved nine seventh grade students. The research participants were categorized by classifying their previous score in their midterm test with the composition of three high achievers, three middle achievers, and three low achievers. To avoid misunderstanding and to appreciate the students' identity, the names appear in this study were identified with specific codes or pseudonyms to represent their classifications. For instance, S1HA refers to the first student in high achiever category; S3MA refers to the third student of middle achiever, and S2LA means the second student of low achiever category, etc.

\section{Data and Source of Data}

There are several research instruments utilized in this study, including (1) the students' spoken stories about visiting a museum in Bandung, and (2) the students' open-ended interviews to discover the possible causes of the students' difficulties in retelling past experiences. Therefore, there are nine students' spoken texts as well as nine transcribed interviews as the source of data in this study. These data are further collected by certain techniques that will be explored further below.

\section{Data Collecting Technique}

The data collection phase was started by asking the students to retell their experiences about three to four minutes regarding their activities to visit the Geology 
Museum in Bandung, West Java. In addition, the students' stories were recorded, transcribed, and analyzed by the researcher to discover the students' difficulties based on the analysis of text organization as well as linguistic features. Moreover, the students were interviewed right after they retell their experiences to discover the possible causes of the difficulties they encounter in retelling past experiences.

In addition, there are four questions for the students to discover the possible causes of the students' difficulties based on their perspectives:

1) Do you have any difficulties in retelling your experience? If so, what are they?

2) Have you ever learned how to use past tense/to retell something in the past previously? Do you have any difficulties?

3) Do you think you ever made errors in retelling experience?

4) In your opinion, what are the possible causes of errors you made while retelling your experience?

After collecting the research data, there are several steps carried out to analyze the research data to answer the research questions. The techniques of analyzing the research data are presented below.

\section{Data Analysis Technique}

There are several steps applied to analyze the data in this study. First, the researcher examines the generic structure and the linguistic features of the students' spoken texts. The generic structure of the students' text is analyzed through the generic structure of recount text that includes orientation, records of events, and reorientation (optional). Second, the linguistic features of the students' texts are analyzed, including the use of specific participants, the use of circumstance of time and place, the use of first person, the use of additive conjunction, the use of material processes, as well as past tense.

In addition, the researcher also analyzes the types of errors that the students' made in their spoken text through Surface Strategy Taxonomy proposed by Dulay, Burt, and Krashen (1987) that include omission, addition, misformation, and misordering. Furthermore, the students' interviews are also analyzed by coding the interview transcriptions to discover the students' responses to the questions, as well as to classify

Premise Journal Vo. 7 No 2, October 2018, e-ISSN: 2442-482x, p-ISSN: 2089-3345, page 15-33 Copyright@2018by 
their responses to answer the research questions. Ultimately, the stages of collecting and analyzing the research data can be illustrated in Table 1 below.

Table 1. Data collection and analysis stages

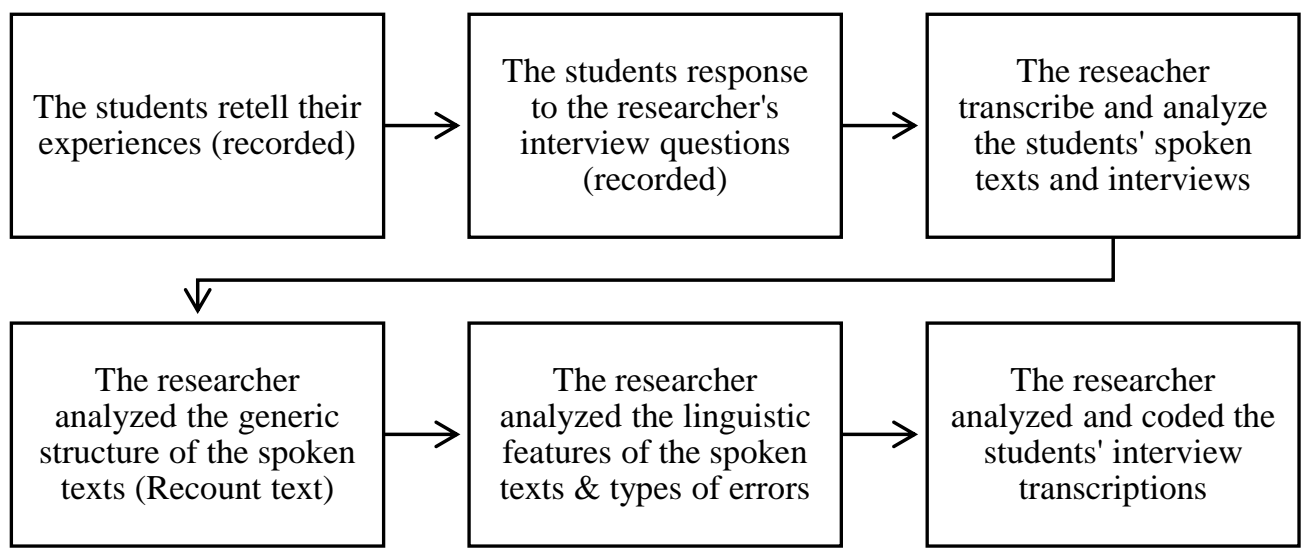

\section{RESULT AND DISCUSSION}

\section{The Generic Structure of the Students' Spoken Text}

Based on the transitivity analysis of the students' spoken texts, it is revealed that all students have developed their story based on the generic structure of recount that includes orientation, series of events, and reorientation (optional part). Furthermore, it is also discovered that the obligatory parts of recount appeared in all students' story, in which they are able to introduce the general information of the event they involved or experienced, as well as elaborate the details of event in their story. Although there are disparities regarding the depth of the information detail that the students provide, they are considered able to fulfill the general characteristics of recount.

However, some students still faced problems in developing their story, including low achiever students who still find it difficult to explore further and introduce the details of their story, such as the detail of people, time, and places involved in their orientation part. For example, S3LA simply introduced the story by stating, "I go to museum". Meanwhile, some other students provided a more in-depth introduction of their stories that enacts as the orientation part. For instance, S2HA introduced the story by elaborating: "Last three weeks, I went Geology Museum with my class. Err my class is divided into four group. My group included Kahfi, Khoir and Toshi..." According to Emilia (2011), the orientation part consists of the background information that informs other people to understand the story, such as the detail of 
people, setting (time and places), etc. In this case, students are considered more successful when they explore more detailed information to introduce their stories as well as to orient the interlocutors into their story.

Although the obligatory parts of recount can be identified in all students' spoken texts, the optional part (re-orientation) can only be found in one student's story (S3MA). In this case, the third middle achiever student expressed his feeling after elaborating the series of events that he experienced while visiting a museum, in which he stated that “[We...] we are very happy and went back with angkot to school at three o'clock. And then, err finally go home by err car and something. That was all." The fact that most of the students did not include reorientation part in their stories, it implies that the students did not emphasize their personal comments about the events they have experienced. Even though it is an optional part which can immerse with the other parts throughout the text, it is suggested that the teacher can provide more understanding that the students can incorporate their personal feeling or comments toward the events they have experienced, such as feeling passionate, happy, etc.

\section{The Linguistic Features of the Students' Spoken Text}

Nine stories of the students are further transcribed and analyzed based on the six linguistic features that are commonly discovered in a recount story. As stated previously, there are several linguistic features that can be found in a recount text, including the use of specific participants, circumstance of time and place, the use of first person to identify the storyteller, the use of additive conjunction, material processes, as well as the use of past tense (Emilia, 2011). Consequently, the linguistic features discovered in the students' spoken texts are further analyzed to determine which linguistic features that the students have commonly made mistakes.

In relation to the linguistic features of the students' spoken texts, it was revealed that there were 223 errors discovered in all the students' stories. The students' errors consist of 136 errors in verb forms, followed by 47 errors in circumstances/adverbs, as well as 40 errors in participant or subject/object within a sentence. Furthermore, the common linguistic features of a recount story have already appeared in the students' stories. However, it is discovered that some students did not apply past tense while retelling their experiences, including one high achiever student and all low achiever students. In addition, the errors in verb forms also relate to the students' difficulties to 
apply past tense forms in their stories. The detail of linguistic features analysis of the students' stories can be identified in Table 2 below.

Table 2. Linguistic features analysis of the students' story

\begin{tabular}{|c|c|c|c|c|c|c|}
\hline \multirow[b]{2}{*}{ Participants } & \multicolumn{6}{|c|}{ Linguistic Features } \\
\hline & $\begin{array}{l}\text { Specific } \\
\text { participant }\end{array}$ & $\begin{array}{l}\text { Circ: } \\
\text { time \& } \\
\text { place }\end{array}$ & $\begin{array}{l}\text { First } \\
\text { person }\end{array}$ & Conj & $\begin{array}{l}\text { Material } \\
\text { process }\end{array}$ & $\begin{array}{l}\text { Past } \\
\text { tense }\end{array}$ \\
\hline S1HA & $\sqrt{ }$ & $\sqrt{ }$ & $\sqrt{ }$ & $\sqrt{ }$ & $\sqrt{ }$ & - \\
\hline S2HA & $\sqrt{ }$ & $\sqrt{ }$ & $\sqrt{ }$ & $\sqrt{ }$ & $\sqrt{ }$ & $\sqrt{ }$ \\
\hline S3HA & $\sqrt{ }$ & $\sqrt{ }$ & $\sqrt{ }$ & $\sqrt{ }$ & $\sqrt{ }$ & $\sqrt{ }$ \\
\hline S1MA & $\sqrt{ }$ & $\sqrt{ }$ & $\sqrt{ }$ & $\sqrt{ }$ & $\sqrt{ }$ & $\sqrt{ }$ \\
\hline S2MA & $\sqrt{ }$ & $\sqrt{ }$ & $\sqrt{ }$ & $\sqrt{ }$ & $\sqrt{ }$ & $\sqrt{ }$ \\
\hline S3MA & $\sqrt{ }$ & $\sqrt{ }$ & $\sqrt{ }$ & $\sqrt{ }$ & $\sqrt{ }$ & $\sqrt{ }$ \\
\hline S1LA & $\sqrt{ }$ & $\sqrt{ }$ & $\sqrt{ }$ & $\sqrt{ }$ & $\sqrt{ }$ & - \\
\hline S2LA & $\sqrt{ }$ & $\sqrt{ }$ & $\sqrt{ }$ & $\sqrt{ }$ & $\sqrt{ }$ & - \\
\hline S3LA & $\sqrt{ }$ & $\sqrt{ }$ & $\sqrt{ }$ & $\sqrt{ }$ & $\sqrt{ }$ & - \\
\hline
\end{tabular}

The fact that students still find it difficult to apply certain linguistic features, such as the use of past tense and verb forms are also in line with the findings of several studies, including a study conducted by Sondiana and Sudirman (2014) in an Indonesian EFL context. Based on their research, it is discovered that the errors of linguistic features that can be found in the students' speech include the errors in verb group, subject-verb agreement, the use of articles, the use of prepositions, noun pluralization, the use of pronouns, as well as the use of conjunctions. Based on the research findings, both researchers argue that the students still experienced difficulties in grammatical systems, particularly in verb forms which dominate the students' errors.

In the current study, further, the students' grammatical errors are analyzed by Surface Strategy Taxonomy to reveal the types of errors that the students produce in their stories. The findings are elaborated further in the next section.

\section{The Error Types of the Students' Spoken Text}

In addition, the grammatical errors discovered in the students' stories are further analyzed through Surface Strategy Taxonomy framework proposed by Dulay, Burt, and Krashen (1987). In general, the researcher discovered that misformation becomes the most frequent errors among other types of errors found in the stories with 121 
occurrences, followed by omission with 79 errors, and 18 addition errors, as well as five misordering errors. For high and low achievers, misformation becomes the most frequent type of errors, followed by omission, addition, misordering. Omission and misformation become the most commonly found types of errors in the middle achievers' stories even though the number of the two types do not differ significantly, followed by addition and misordering. The misformation errors are mostly dominated by the incorrect use of past tense while retelling the students' experiences. The information of the error types discovered in the students' stories can be discovered further in Table 3.

Table 3. Types of students' errors based on Surface Strategy Taxonomy

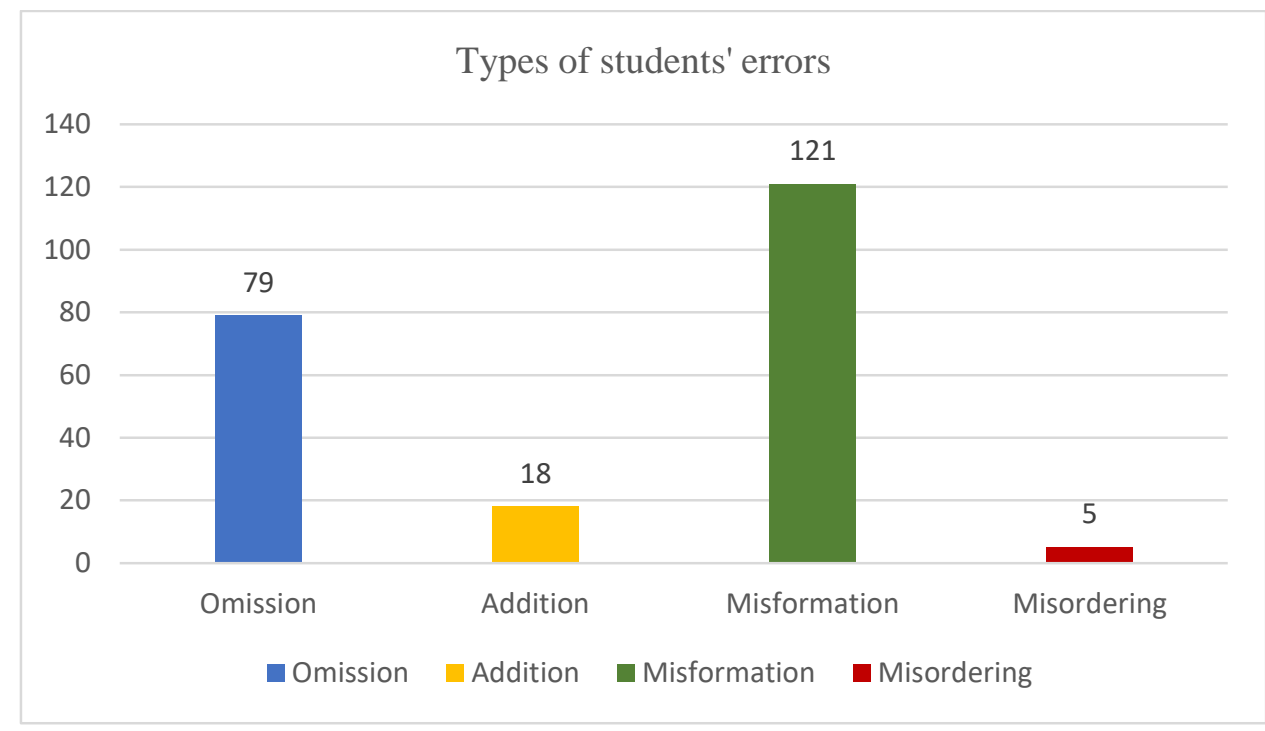

Based on the research findings, it is revealed that misformation and omission dominate the error types produced by the students in their spoken texts. These findings are also in line with the other empirical studies, including a study conducted by Sembiring (2017) in the Indonesian EFL setting. The study conducted by Sembiring (2017) reveals misformation is the most dominant error type in the students' spoken texts, followed by omission. The misformation error produced by the students is closely related to the wrong use of word formation in verb agreement. This is also in accordance with the current study, in which the students find it difficult to apply the accurate verb forms while retelling past experiences. 
To discuss the generic structure, the linguistic features, as well as the types of errors further, there is one story that will be presented to portray the example on how the research findings are analyzed and further discussed to answer the research questions:

Table 4. The analysis of S3MA's story

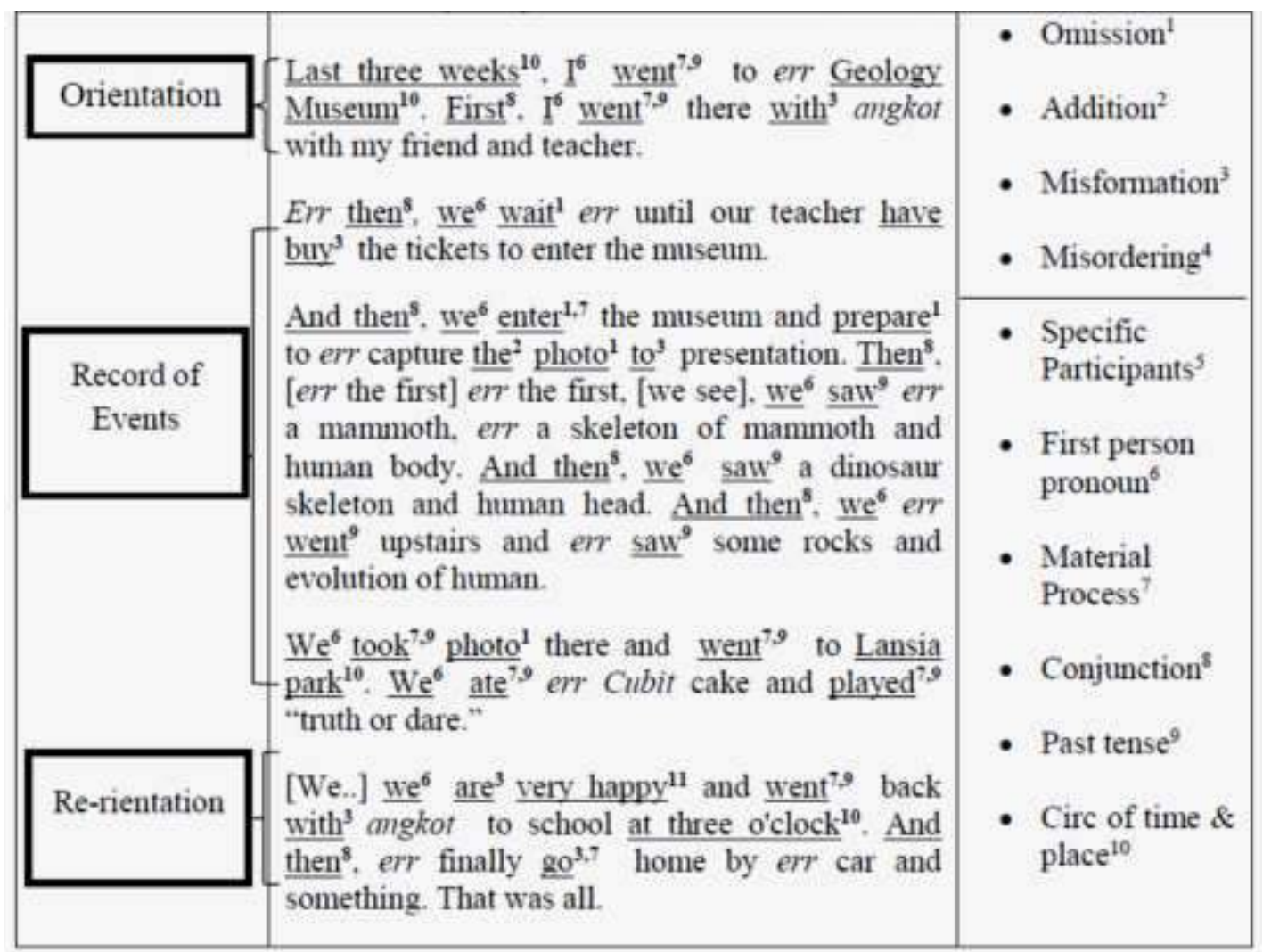

In relation to the generic structure, the obligatory parts of the recount (orientation and series of events) can be identified. Furthermore, he mentioned the detail of time, place, as well as other subjects in the orientation part to introduce the story to the interlocutors. In addition, the student also made the transition between the orientation part to the series of events by stating his story while waiting for his teacher to buy the tickets for the students, and the activities inside the museum, the activities at the Lansia park. At the end of the story, the student outlined his personal feeling toward the event he had experienced by stating, "we are very happy" then concluded the story by mentioning "That was all". Generally, it can be stated that the student is able to retell his story with the standard structure of a recount story though there are several errors regarding linguistic features that will be explained further in the next paragraphs. 
Regarding the linguistic features of a recount story, the student had already applied all linguistic features of a recount as suggested by Emilia (2011), such as the use of specific participant $(I)$, the use of first person (I, we), the use of circumstance of time and place (Last three weeks, Geology museum, etc.), conjunction (and then, first..., etc.), material process (went, took, played, etc.), past tense (saw, went, etc.). The student, however, still find it challenging to apply some grammatical features accurately since there were 14 errors in the story that consists of six occurrences of process/verbal forms, six occurrences of participant errors, and two errors in circumstance.

After being analyzed by surface strategy taxonomy, it is also revealed that the errors consist of eight omission and six misformation errors. Each type of errors will be elaborated below. In relation to the omission errors, there are eight omission errors that consist of four omissions of morpheme -es/-s to describe plurality, three omission of morpheme -ed/-d to retell past events and one omission of the article. One example of omission error in the story is "then, we wait until our teacher...". Minor problems of tense were identified in the student's story, in which there were three errors in the process/verb forms that signify the student's difficulties in applying the correct verb form. The example presented above revealed that the student did not apply the correct process/verb form in the past. The process/verb 'wait' should be 'waited'.

Furthermore, there were six misformation errors consisted of three archi-form and three alternating form of misformation. One archi-form misformation error is presented here: "we are very happy". This sentence consists of one archi-form of misformation, in which the relational process 'are' should be in the past form since the student was retelling his previous experiences to visit a museum. Regarding the alternating form of misformation, the student also stated: "First, I went there with angkot [public transport]" In this case, the student used the conjunction "with" instead of "by" in the sentence. It is argued that it is due to the similar meaning between the two words when they are directly translated to Bahasa Indonesia. Consequently, the student might think that either word can be applied in the sentence.

Although addition and misordering do not appear in the students' stories significantly, it is still considered essential to discuss both types. One example of addition is presented from S2MA's story in which the student is still confused to apply 
appropriate preposition in circumstance/adverbs: "after that, we went to upstairs". In relation to misordering error, one example is presented from S1LA, in which the student stated: "After that, we eat cake Cubit Green Tea." In this case, the student made an error regarding the order of word "cake" and "Cubit Green Tea" to form a phrase "Green Tea Cubit cake". It is argued that the student either still does not understand the strategy to describe the thing in English. Consequently, the student simply expressed the thing with Bahasa Indonesia-like structure.

\section{The Causes of Students' Difficulties}

After interviewing nine participants, some findings were discovered regarding the causes of students' difficulties in retelling their stories. It is argued that there are three major causes of the students' difficulties to retell their experience, including the lack of understanding to apply correct tenses and verb forms, the lack of vocabularies, and nervousness/anxiety due to lack of exercise. All students asserted that they encounter difficulties in applying correct tense while retelling experiences, particularly when they attempted to apply the regular and irregular form of verbs (process). One example presented below was taken from the interview between the researcher and S1MA, in which the student stated that the cause of the difficulties, when recounted the experience, was that the student still did not understand how to apply tense correctly.

$\begin{array}{ll}\text { Interviewer: } & \begin{array}{l}\text { Based on your perception, what is the cause of } \\ \text { the difficulties and errors while retelling the } \\ \text { experiences? }\end{array} \\ \text { S1MA: } & \text { I still do not understand } \\ \text { Interviewer: } & \begin{array}{l}\text { Can you elaborate more? } \\ \text { S1MA: }\end{array} \\ & \begin{array}{l}\text { I still do not understand how to change the } \\ \text { present to the past form. So that I do not know } \\ \text { the past form of the verb. }\end{array}\end{array}$

Consequently, it is argued that the students are still confused about applying the past form of the verb while retelling their past experiences in visiting a museum. In addition, the lack of understanding of vocabularies can be found in the students' interview that will be explored further in the next paragraph.

Furthermore, some students also highlight their difficulties to understand unfamiliar or new vocabularies when they need to use it in their stories. For instance, S3HA mentioned that it is challenging for the student to determine whether particular verbs/processes are considered as regular or irregular forms due to the unfamiliarity of the words. In this case, it is argued that the students still have limited stocks of 
vocabularies to retell their experiences further or when they want to express certain activities in the past. The excerpt of the interview between the researcher and S3HA student is presented below:

Interviewer: Do you have any difficulties when retelling your experience using past tense?

S3HA: $\quad$ I find it difficult to decide whether this word is regular or irregular verb, especially for the new words

In this case, the students still find it difficult to determine whether he needs to change the words into regular or irregular forms since the student is not familiar with the words that he encountered. Consequently, it is suggested that teachers can emphasize the students' understanding to utilize both present and past form of certain verbs/processes.

Besides the two causes of students' difficulties, it is also discovered that anxiety or nervousness also affect the students' difficulties or errors while retelling past experiences. Based on the interview with S2HA, the student stated that he was feeling nervous while retelling past experiences. Furthermore, another student such as S3HA also added that he was feeling rushed to conduct the activity due to the anxious feeling that he experienced. The interview excerpts between the researcher and S2HA, as well as S3HA, are presented below:

$\begin{array}{ll}\text { Interviewer: } & \begin{array}{l}\text { Do you have any difficulties when retelling } \\ \text { your experience using past tense? }\end{array} \\ \text { S2HA: } & \begin{array}{l}\text { Yes, I have. } \\ \text { Interviewer: }\end{array} \\ \text { ShHA is it difficult for you? } & \begin{array}{l}\text { It is because I am nervous and afraid of } \\ \text { making mistakes }\end{array} \\ \text { Interviewer: } & \begin{array}{l}\text { In your opinion, what are the causes of your } \\ \text { difficulties to retell the story? }\end{array} \\ \text { S3HA: } & \begin{array}{l}\text { Ifeel rushed } \\ \text { Interviewer: }\end{array} \\ \text { S3HA: } & \text { I also feel nervous }\end{array}$

Based on the findings, it can be revealed that the students' difficulties are caused by the lack of understanding regarding vocabularies and verb use, as well as the feeling of anxiety/nervousness. This finding is line with the study conducted by Haidara (2016), in which he argues that the students' anxiety is caused by the students' fear of making mistakes during the classroom activities. This psychological feeling can further 
give negative impacts on the students' speaking performance (Haidara, 2016). However, Saputra (2017) argues there are two types of anxiety, including negative and positive sides of anxiety which can play a significant role in students' speaking skills. The positive sides of anxiety can further motivate the students in learning English (Saputra, 2017). Consequently, it is considered vital to rebalance the students' proportion of anxiety to give positive impacts toward the development of their speaking skills.

\section{CONCLUSION AND SUGGESTION}

Based on the analysis of the research data, it is argued that the students have already developed their recount story based on the appropriate generic structure of recount texts. This is revealed since the obligatory parts of recount appeared in all of the students' spoken texts. In other words, the students are considered capable of explaining information needed at the beginning of their stories and were able to retell series of events they experienced while visiting a museum. Although the students are generally able to fulfill the required criteria of recount scheme, low achiever students still find it difficult to develop their stories further. In addition, it is also discovered that most of the students did not include reorientation in their stories. Although this part is considered as an optional part, teachers are suggested to highlight the importance of incorporating the students' personal feeling/remark toward the events they had experienced, such as feeling excited, energized, unhappy, etc.

In relation to the linguistic features, it is discovered that some students still find it difficult to apply one major linguistic feature of recount, namely past tense. However, all students have applied other features accurately such as mentioning specific participants in their story, applying the first-person pronoun, using the circumstance of time and place, as well as applying conjunction to link the series of events in their stories. Regarding the types of errors analyzed through Surface Strategy Taxonomy framework, the students' errors are mainly dominated by misformation, followed by omission, addition, and misordering. Based on the interview with the students, it can also be discovered that the students encounter speaking difficulties due to three primary reasons, including the lack of understanding in verb forms, the lack of vocabularies, as well as anxiety/nervousness feeling experienced by the students while producing spoken texts.

Premise Journal Vo. 7 No 2, October 2018, e-ISSN: 2442-482x, p-ISSN: 2089-3345, page 15-33 Copyright@2018by 
Ultimately, this research also provides several suggested practices for teachers in the EFL classroom. First, teachers should provide exposures to the students about how to develop the stories or texts with appropriate structure and other features, so that the students can comprehend how to retell experience appropriately. It is also suggested to inform the students that they can also include their personal comments toward the events or moments they experienced in the story. Second, teachers should also engage the students with certain speaking activities which allow the students to practice their speaking competence with anxiety-free and friendly learning atmospheres. Therefore, it is expected that the students can enhance their confidence level that eventually impacts positively on the students' speaking accuracy and fluency.

This research also provided some suggested directions for researchers in the relevant field. First, this study can be a reference for other researchers who are interested in analyzing the relevant issue. In addition, the other researchers can also analyze the students' difficulties in the other text types or contexts, such as describing, reporting, etc. Analyzing the learners in different level is also vital to enriching the related field. Second, the researchers can also focus on the practical interventions or activities that can reduce the students' difficulties in speaking activities. Since this research has already revealed several difficulties experienced by the students, the other researchers can focus on lowering the students' difficulties through certain practical activities in the classroom.

\section{ACKNOWLEDGMENT}

The author would like to acknowledge the help of Mr Willy Juanggo, S.Pd., M.A., as the homeroom teacher of 7A, who had granted permission for the author to conduct the study at 7A class in Pribadi Bilingual Boarding School Bandung. Furthermore, the author would like to express his gratitude toward the students of 7A Pribadi Bilingual Boarding School Bandung who participated in this study.

\section{BIO-PROFILE}

Yogi Saputra Mahmud holds his Bachelor of Education degree (English Education) from the Indonesia University of Education (UPI). He has several years of teaching experiences in Pribadi Bilingual Boarding School Bandung. Currently, he is pursuing his Master of TESOL degree at Monash University, Australia. His research

Premise Journal Vo. 7 No 2, October 2018, e-ISSN: 2442-482x, p-ISSN: 2089-3345, page 15-33 Copyright@2018by 
interests include curriculum and material developments, productive skills, and preservice teachers' training. Corresponding email: yogisaputramahmud@gmail.com, yogi.mahmud@monash.edu.

\section{REFERENCES}

Agustina, T. (2016). Error analysis in writing recount text. JoLLiET (Journal of Literature, Linguistics, and English Teaching), 3(1), 81-89. Retrieved from http://journals.ums.ac.id/index.php/JoLLIET/index

Al-Hosni, S. (2014). Speaking difficulties encountered by young EFL learners. International Journal on Studies in English Language and Literature (IJSELL), 2(6), 22-30. Retrieved from https://www.arcjournals.org/international-journalon-studies-in-english-language-and-literature

Creswell, J. W. (2012). Educational research. Boston: Pearson Education, Inc.

Dalem, M. (2017). Difficulties of speaking that are encountered by English language students at Al Margeb University. Premise : Journal of English Education and Applied Linguistics, 6(2), 20-29. Retrieved from http://fkip.ummetro.ac.id/journal/index.php/english

Dulay, H., Burt, M., \& Krashen, S. (1987). Language two. New York: Oxford University Press.

Emilia, E. (2011). Pendekatan Genre-Based dalam pengajaran bahasa Inggris: Petunjuk untuk guru. Bandung: Rizqi Press.

Fauziati, E. (2011). Interlanguage and error fossilization: a study of Indonesian students learning English as a foreign language. Indonesian Journal of Applied Linguistics, 1(1), 25-40. Retrieved from http://ejournal.upi.edu/index.php/IJAL

Haidara, Y. (2016). Psychological factor affecting English speaking performance for the English learners in Indonesia. Universal Journal of Educational Research, 4(7), 1501-1505. Retrieved from http://www.hrpub.org/journals/jour_info.php?id=95

Hamid, R., \& Qayyimah, Q. (2014). An error analysis in the use of past tense in writing recount text at the second year students of SMP UNISMUH Makassar. Exposure Journal, 3(1), 16-28. Retrieved from http://journal.unismuh.ac.id/index.php/exposure/index

Hermini, H. (2015). Grammatical error analysis in recount texts made by the students of Cokroaminoto University of Palopo. Ethical Lingua, 2(1), 87-101. Retrieved from https://journal.uncp.ac.id/index.php/ethicallingua

Hidayati, S. (2011). Error analysis on a short story: a Case of an ESL Indonesian learner. E-CLUE (Journal of English Culture, Language, Literature and Education), 5(1). Retrieved from https://staffnew.uny.ac.id 
Hojati, A. (2013). An investigation of errors in the oral performance of advanced-level Iranian EFL students. Mediterranean Journal of Social Sciences, 4(4), 171-179. Retrieved from http://www.mcser.org/journal/index.php/mjss/index

Juhana, J. (2012). Psychological factors that hinder learners from speaking in English class. A case study in a senior high school in South Tangerang, Banten, Indonesia. Journal of Education and Practice, 3(12), 100-110. Retrieved from https://iiste.org/Journals/index.php/JEP

Khamkhien, A. (2010). Teaching English speaking and English speaking tests in the Thai context: A reflection from Thai perspective. English Language Teaching, 3(1), 184-190. Retrieved from http://www.ccsenet.org/journal/index.php/elt

Lampiran Peraturan Menteri Pendidikan dan Kebudayaan Nomor 21 Tahun 2016 tentang Standar Isi Pendidikan Dasar dan Menengah. (2016). Jakarta: Ministry of Education and Culture Retrieved from http://bsnp-indonesia.org/.

Noprival, N. (2016). Students' voice: EFL speaking problems on English day program at one senior high school in Indonesia. Jurnal Ilmiah Universitas Batanghari Jambi, 16(1), 77-81. Retrieved from http://ji.unbari.ac.id/index.php/ilmiah

Saputra, J. B. (2018). An analysis of students' speaking anxiety toward their speaking skill. Premise : Journal of English Education and Applied Linguistics, 7(1), 111-123. Retrieved from https://fkip.ummetro.ac.id/journal/index.php/english

Sayuri, S. (2016). English speaking problems of EFL learners of Mulawarman University. Indonesian Journal of EFL and Linguistics, 1(1), 47-61. Retrieved from http://www.indonesian-efl-journal.org/index.php/ijefll

Schleppegrell, M. J. (2004). The language of schooling. A functional linguistics perspective. New Jersey: Lawrence Erbaum Associates.

Sembiring, L. T. A. B. (2017). An analysis of students' errors on storytelling presentation in English Department, University of Dehasen Bengkulu. Vision: Journal for Language and Foreign Language Learning, 6(1), 21-32. Retrieved from http://journal.walisongo.ac.id/index.php/vision

Sondiana, S. D., \& Sudirman, A. M. (2014). An analysis of grammatical errors in speech at the students of English education study program of Muhammadiyah University of Metro academic year 2013/2014. Premise : Journal of English Education and Applied Linguistics, 3(2), 1-13. Retrieved from http://fkip.ummetro.ac.id/journal/index.php/english

Sudjasmara, D. B. (2013). The difficulties encountered by non-English department students in speaking English. Indonesia University of Education, Bandung. Retrieved from http://repository.upi.edu/5329/

Yang, Y. T. C., \& Chang, L. Y. (2008). No improvement: Reflections and suggestion on the use of Skype to enhance college students' oral English proficiency. British Journal of Educational Technology, 39(4), 721-725. doi:10.1111/j.1467-8535.2007.00769.x 